\title{
Making Of The Modern Sweden
}

\section{Ahmet Can KARAPINAR*}

\begin{abstract}
Sweden is today's one of the wealthiest countries in the world. The reasons behind this success could only be understood with a historical perspective. While looking to the history of Sweden, I realized three distinctive events which shaped Swedish culture, society, politics and economy significantly. Beginning with the early modern period in the $16^{\text {th }}$ century and ending with the modern period in the second half of the $19^{\text {th }}$ century, these three events are (in the chronological order) Swedish Reformation and the reign of Gustav I in $16^{\text {th }}$ century, the rise of the Swedish Empire in $17^{\text {th }}$ century and the industrial development in Sweden during the second half of the $19^{\text {th }}$ century.

In this article, the effects of these three events would be analyzed in terms of their influence on the Swedish culture, state bureaucracy, politics, society, religion, economy and military with their backgrounds. The study on the backgrounds of these event show that these influenced each other strongly. Not only this, but also the influence of them shaped Sweden as it is today. Given today's high life standards, the making of modern Sweden is a success story and understanding it with a historical analysis could be helpful for policy makers all around the world.
\end{abstract}

Keywords: Sweden, Reformation, Gustav I, Swedish Empire, Industrialization, Modern Sweden

Jel Codes: N13, N33, N43, N63, N93, O52

\section{Modern İsveç'in Oluşumu}

\section{Özet}

İsveç, günümüzün refah seviyesi en yüksek ülkelerinden biridir. Bu başarının arkasında yatan sebepler, sadece tarihsel bir perspektifle anlaşılabilir. İsveç tarihine bakıldığında, ülkenin kültür, toplum, siyaset ve ekonomisini şekillendiren üç belirgin olayın

\footnotetext{
*Researcher-Writer, Istanbul,Turkey, ahmetcankarapinar@gmail.com
} 
öne çıktığını fark ettim. 16. yüzyılda erken modern dönemle başlayıp, 19. yüzyılın ikinci yarısında modern dönemde biten bu üç olay (kronolojik sırayla), 16. yüzyıldaki İsveç Reform Hareketi ve I.Gustav dönemi, 17. yüzyıldaki İsveç İmparatorluğu'nun yükselişi ve 19. yüzyılın ikinci yarısında İsveç’teki endüstriyelleşme hareketidir.

Bu makalede, bu üç olayın etkileri İsveç kültürü, devlet bürokrasisi, siyaseti, toplumu, dini, ekonomisi ve askeriyesi üzerindeki tesirleri ve arka planlarıla beraber analiz edilecektir. $\mathrm{Bu}$ olayların arka planları üzerine olan çalışma, birbirleri üzerinde güçlü etkileri olduğunu göstermiştir. Ayrıca bununla sınırlı kalmayıp, onların etkisi günümüz İsveç’ini şekillendirmiştir. Günümüzün yüksek hayat standartları göz önünde bulundurulduğunda, modern İsveç'in oluşumu bir başarı hikâyesidir ve bunu tarihsel bir analizle anlamak dünya çapında karar verici mevkilerde bulunanlara yardımcı olabilir.

Anahtar Kelimeler: İsveç, Reform, Gustav I, İsveç İmparatorluğu, Endüstriyelleşme, Modern İsveç

Jel Kodlar: N13, N33, N43, N63, N93, O52

\section{Introduction}

Today's Sweden is among the top of the indexes which measure the life quality such as GDP per capita or Human Development Index (HDI). The country is known for its high education levels, well functioning health care system and the welfare state. In terms of both internal and external violence levels, it is a safe and peaceful country. In the international arena, since taking part in the Napoleonic Wars in 1814, the country kept its neutrality. Only in this last decade, Sweden is taking a more active role in military cooperation with various European countries and NATO. Economically too, Sweden's rise in the last century is a remarkable story. Then one might ask how Sweden did become the Sweden as we know today. In order to understand that, one need to have a historical perspective.

In this study, three phenomena from the Swedish history are studied. These three phenomena shaped the Swedish culture, politics, economy and society remarkably and are crucial to understand the making of the modern Sweden. First two are from the early modern period, which is one of the most influential periods of history which shaped not only Sweden but the Europe and the world as a whole. The first phenomenon is Swedish Reformation and the reign Gustav I of Sweden in $16^{\text {th }}$ century. The Reformation movement and Gustav I of Sweden influenced the culture and state making processes of Sweden more than any other 
rulers of the country. The second phenomenon is more focused on the politics and military: The rise of the Swedish Empire. Although, Sweden was a major European power in $17^{\text {th }}$ century, today it is not very well known and it is an area which needs to be studied more.

The last milestone event in this study on the making of the modern Sweden is the industrial development in the country. Sweden, although missing much of the beginning of the Industrial Revolution managed to catch up with other industrial countries in the second half of the $19^{\text {th }}$ century. The developments which took place at that time shaped both society and economics of that country significantly.

My article is presented, offering a historical perspective on the making of the modern Sweden by studying the three milestone events which shaped the country.

\section{Swedish Reformation and Gustav I of Sweden}

History of Sweden is an inseparable part of the early modern European history, specifically northern Europe's history. In the $16^{\text {th }}$ century, gaining her independence from Denmark with Swedish War of Liberation / Gustav Vasa's Rebellion (1521 - 23), until the $18^{\text {th }}$ century, defeat of Swedish forces in the Battle of Poltava (1709), Sweden was a major European power which influenced politics, society and religion of the Europe.

Religion part is the one of the most important of these influences. Swedish War of Liberation happened during the years of a great tension in terms of religious and political controversies in Europe: the Reformation. Started in 1517 in Wittenberg, Germany with ninety-five theses nailed to the door of the castle church, regarding the indulgences and related topics, the Reformation movement changed the religious and political map of Europe completely. It gave way to the Catholic Reformation and Thirty Years' War (1618 - 48). It resulted in the foundation of the Protestant, Calvinist and Anglican churches and created a great schism in the Christian world with the Catholics. With the Reformation, Pope's absolute authority over European monarchs had been broken. Later this will have significant effects on the centralization and emergence of the nation states and shaping today's world.

Sweden, in this Reformation movement, had a significant role. It is true that the Reformation started in Germany. German cities played an important role in the spread of ideas of the Reformation. Its universities were centers of learning. There was a developed urban culture and usage of printing press. All these, made possible the Luther's ideas to spread throughout the Europe. So, it is not a surprise that Germany's next door neighbors Denmark, Norway and Sweden converted to the Protestant faith. These Scandinavian countries were the only states outside Germany where Lutheranism became the state religion. 
However, the dynamics between Scandinavian countries and Germany in this conversion to Lutheranism were quite different. Before discussing that, it would be more appropriate to look to the background on the history of the Christianity in Sweden.

\subsection{Background of the Swedish Reformation}

Before the Reformation movement, Sweden was a Catholic country. According to Inge Jonsson in the Swedish Culture in a European Context, first known missionaries came to Sweden around the year 830, a Frankish Benedictine named Ansgarius (Jonsson, 1999: 149). However Jonsson claims that, this did not had a significant impact, "recent studies point to influences from England as more important than the Frankish missionaries"' (Jonsson, 1999: 149). The country did not become mainly Christian until $12^{\text {th }}$ century. It was only in 1164 when an archbishop was installed in Old Upsala (should not be confused with Uppsala, later and still main seat of the church), Sweden became an independent ecclesiastical province (Jonsson, 1999: 149). Uppsala became an important center for studying Latin and theology until the $16^{\text {th }}$ century. Till that time $\left(16^{\text {th }}\right.$ century), Sweden was loyal to the Roman Catholic Church.

Before starting to explain the Reformation movement in Sweden, some information on the political atmosphere of that time would be helpful. In 1397, Denmark, Sweden (Finland was incorporated to Sweden in the $13^{\text {th }}$ century) and Norway united under one crown: Kalmar Union. Denmark, Sweden and Norway although having much in common were separate until that time. However Kalmar Union, according to Andrew Back in The Rise and Fall of Catholic Sweden, “...was purely a dynastic measure, and each country retained its own laws and customs"' (Beck, 1940: 388). Not only this, but also Back claims that the consequences for the three kingdoms and the Church, were disastrous (Beck, 1940: 388). The royal power in the Kalmar Union was not hereditary but elective. So the clashes between feudal families were inevitable. Also resistance to the autocracy and domination of the Denmark, civil war, treaties, broken promises and bloodshed were marks of the Kalmar Union (Beck, 1940: 388), according to Back. It was such an atmosphere where the Reformation movement in the Sweden had started.

The clash between feudal families of Trolle and Sture to rule the Sweden under Kalmar Union was very important (Beck, 1940: 388). Svant Sture (1460 - 1512), the Protector of the Sweden at that time, who led a national uprising against the Danes died in 1512. This started the unrest in Sweden and the conflict accelerated with the Danish King Christian II's (1481 - 1559) involvement. The Archbishop of Uppsala sided with the Danish 
King and this was seen as a "treacherous act' by the Swedish insurgents. King Christian II of Denmark won the war in 1520 and entered Stockholm. The infamous " Stockholm Bloodbath (8 November 1520)", massacre of the insurgents who were promised an amnesty, led to a new rebellion: Gustav/ Gustavus Eriksson's or better known as Gustav Vasa or Wasa's rebellion (also known as Swedish War of Liberation). According to Back, Stockholm Bloodbath was the end of the Kalmar Union and the point which Swedish national sentiment turned against the Roman Catholic Church completely (Beck, 1940: 390).

\subsection{Swedish Reformation and the Rise of Gustav I}

In, The Reception of the Augsburg Confession in Scandinavia, Trygve R. Skarsten studies on the Lutheran character of the Gustav Vasa's Rebellion. He emphasizes that, election of Gustav Vasa (also known as Gustav I of Sweden, 1496 - 1560) as the leader of the insurgents (and also as the king of the Sweden) happened in the city of Strengnas in 1523, where Olaus Petri (1493 - 1552), a disciple of Luther, were preaching (Skarsten, 1980: 183). Olaus Petri is known as the "Luther of Sweden"' and he introduced the Luther's teachings to Sweden as early as 1518. Gustav Vasa influenced from Olaus Petri's Lutheran preaching and adding the anti-Catholic sentiments of Swedes, Gustav Vasa started to follow a Reformist program in terms of religion. At the end of the 1523, Gustav Vasa's forces entered Stockholm and on 1 September 1524, with the Treaty of Malmö, Sweden gained her independence. However this did not end the Reformation in Sweden. From the beginning of his reign, Gustav Vasa was determinate to subordinate the Church into his and state's needs.

In 1523, he cut the official communication with the Papacy because of latter's interference in the Swedish ecclesiastical affairs. The decisions Gustav Vasa took against the Church's authority had not end there. He confiscated many of the church property and land. He ended church's economic independence, so the church is subordinated to the Crown. He eradicated the monastic culture in Sweden. According to Jonsson, all this was to restore economic order after the war which was damaged significantly (Jonsson, 1999: 151). Jonsson praises Gustav Vasa's success in restoring the economic balance. He claims that Gustav Vasa's inventiveness and approach to the government expenditures served as a model until this very day (Jonsson, 1999: 151).

The Reformation in Sweden was not restricted to the political and economic affairs:

Olaus Petri and his brother were quite active in 1520s Reformation movement in Sweden. They were among the main contributors who founded the theological base of the Swedish Reformation. In the theological base, it was quite similar to Martin Luther's teachings. One 
should not forget that Olaus Petri studied in Wittenberg, where Martin Luther started the Reformation. Not only this but also translation of the New Testament to the Swedish (and later to the Finnish) took place at that time. Örebro Synod of 1529 is important in this theological aspect too. In the Synod, the performance of the rituals such as baptism, wedding, funeral and pilgrimage discussed and the Catholic way was either banned or discouraged. The King and the Swedish Diet officially declared Sweden as a Lutheran nation in 1544. Although after the death of the Gustav Vasa in 1560, there were some efforts among the nobles and even in the royal family (Gustav Vasa's family, unlike Gustav Vasa's election it was hereditary after him) to return to a reformed Catholic faith. But with the year 1593, it was clear that Augsburg Confession was the official confession of the National Church.

These prohibitions regarding the Catholic faith were quite strict. Rune P. Thuringer in The Catholic Church in Sweden, gives detailed accounts of this prohibition. He asserts that, in 1617 there came an absolute ban on the Catholic faith "implying capital punishment for Swedish citizens who became Catholics" (Thuringer, 1973: 70). In 1781, only foreign merchants were allowed to practice Catholic faith and only as late as 1873, Swedes were allowed to leave the State Church and enter the Catholic Church (Thuringer, 1973: 70). For the Religious Freedom Act to be proclaimed, it would take 79 years more (1952) (Thuringer, 1973: 71). Until the year 2000, Swedish Church held the position of state church.

\subsection{Consequences and Effects}

As one could guess, this Reformation was not without its repercussions. Reformation led to the several uprisings mainly Westrogothian Rebellion of the nobility in 1529 and Dalecarlian Rebellions of the peasantry in 1520s and 1530s. Their main aim was to stop the Swedish Reformation. Although latter one had economic reasons too, it shows that the antiCatholic sentiment was not shared all along the country. All of the rebellions crushed by the Gustav Vasa's forces. In the years 1598 - 99, a war broke out between Sweden and Poland on the succession issue but also it had a religious character which aimed "Catholicizing" the Sweden but Poles got defeated.

The Swedish Reformation's influence on the Swedish Renaissance is quite interesting. Unlike the relation between its European counterparts (although controversial), Swedish Reformation had a negative effect on the Swedish Renaissance generally. Simon McKeown, in the Reading and Writing the Swedish Renaissance tries to answer a very simple question: Why? He finds several reasons. First and foremost of them is the broken function of the Church's in cultural and educational affairs. Uppsala was no longer a center of education (till 
its revival in the $17^{\text {th }}$ century). Until that time, the Church was promoting a vivid educational activity (especially in theology and Latin) but now it is "gone" and there was not anything to replace it in the $16^{\text {th }}$ century.

Another reason is related to the personality of the Gustav Vasa. According to McKeown, "Gustavus Vasa exerted close control over all published writings in the kingdom" (McKeown, 2009: 141). In 1526, he shut down all printing presses in Sweden except one in Stockholm (McKeown, 2009: 141). The remaining one's only function was the publication of the royal proclamations and prayer books (McKeown, 2009: 141). So, unlike Germany, where printing press had a significant impact in the discussions and dissemination of ideas (positively effecting the Renaissance), Sweden lacked this aspect. McKeown claims that, only after the Gustav Vasa's eldest son's Erik's accession to the throne in 1560, it is possible to study a Swedish Renaissance. So, these are the some answers to the question of "why northern Europe had a late Renaissance".

However this does not mean that, during the Gustav Vasa's reign there was not any development about a Swedish Renaissance. Joseph Gonzalez in the Rewriting History: Humanist Oration at the Funeral of Gustav Vasa, 1560 studies on the funeral oration and ceremony of the Gustav Vasa and it is possible to see the effects of the Renaissance thinking at there. Gonzalez puts special emphasis to funeral orations of the early modern Europe. According to him, in the funeral orations there are important messages regarding the political ideology and discourse (Gonzalez, 2006: 123). He analyzes the oration line by line and takes our attention to the overall "humanist" voice. This humanist voice is a common aspect of the Renaissance thinking and we can see that a Swedish Renaissance (although very slow) was already began during the reign of the Gustav Vasa.

\subsection{Conclusion on the Swedish Reformation and Gustav I of Sweden}

In conclusion, Swedish Reformation is unique in its characteristics. It is different from the German Reformation movement because, despite the general anti-Catholic sentiments among the Swedes, the reforms were taken by the Crown, the above. There was not any demand or the movement of the below regarding that. It is different from the other Scandinavian Reformation movements (the Danish one). Because for the King Christian II of Denmark, the Reformation was nothing more than a political tool. However for the King Gustav Vasa of Sweden, the Reformation was a crucial element in the revival of his nation. Gustav Vasa's autocratic ambitions shaped the Reformation process in Sweden significantly. Not only this, but also Sweden's involvement in the Thirty Years' War is credited with saving 
Protestantism in Germany (Encyclopedia Britannica, 2013). These events created the Sweden as a major power of Europe and shaped the future of the country. Even today, discussions about the politics and society of the Sweden could not be understood without studying the Swedish Reformation and the reign of the Gustav I of Sweden.

\section{The Rise of the Swedish Empire}

In the $17^{\text {th }}$ century, Sweden was a great power. Its armies fought throughout Germany and central Europe. Swedish Navy dominated the Baltic Sea (Arrsion, 1994: 158). Sweden conquered territories of Norway and territories on the eastern (today's Estonia) and southern shores of the Baltic Sea. Sweden developed a successful and efficient military organization and was often victorious despite being outnumbered most of the time. Its successes were not only limited to the military. In the international arena, it was Sweden who was credited with saving Protestantism in Germany. Its alliance with France had major influences on the European politics of the $17^{\text {th }}$ century. In the national politics, Sweden was known for its efficient and centralized (in the context of the $17^{\text {th }}$ century) bureaucracy and administration. In terms of economy too, tax collection was efficient and trade activities were prospering. Not only this, but also Sweden had colonies or trading posts in North America, Caribbean and Africa. Although most of them failed, they are important examples to show the extent of the Swedish imperial power.

\subsection{Background of the Rise of the Swedish Empire}

Then comes the question: Why Sweden became a great power in the $17^{\text {th }}$ century? How can one explain the rise of the Swedish Empire? There are many reasons to explain the rise of the Sweden in the $17^{\text {th }}$ century but before starting that, it would be more appropriate to look to the background. The events which took place in the $16^{\text {th }}$ century are crucial to explain the rise of the Sweden in the $17^{\text {th }}$ century.

At the end of the 1523, Gustav Vasa's (also known as Gustav I of Sweden) forces entered Stockholm and on 1 September 1524, with the Treaty of Malmö, Sweden gained its independence. Although Swedish Empire's beginning is usually taken as the reign of Gustavus Adolphus (1594 - 1632 / r. 1611 - 1632), who ascended the throne in 1611, one should study the reign of the Gustav Vasa $(1496$ - 1560 / r. 1523 - 60) to understand the background. 
Gustav Vasa followed an autocratic rule in Sweden. He started the Reformation movement in Sweden and was determinate to subordinate the Church into his and state's needs. He also followed intense centralization and state building activities under his autocratic rule. When he died in 1560 , he left a Sweden which was ready to be a great power in the coming years. Since we looked to the background of the political atmosphere, now is the time to explain the rise of Sweden in the $17^{\text {th }}$ century.

\subsection{How did Sweden become a great power?}

\subsubsection{Natural Resources}

First of all, Sweden was rich in natural resources such as iron, copper, silver, wood, tar and herring (made into oil). Access to copper and silver were positive elements in the monetization of the economic activities. Monetization of the economy meant increasing economic effectiveness. Bartering could not give as much as efficiency as monetized economies could give. Also, natural resources such as iron and timber had military usages. Sweden's efficient armies were "supplied by arms domestically manufactured from Sweden's major copper and iron mines", (University of Wisconsin-Madison). Another natural resource, timber was crucial for the ship building. So, Swedish domination in the Baltic Sea and colonization activities could not be done without timber production.

\subsubsection{Political Stability and Bureaucratic Efficiency}

In terms of political stability and bureaucratic efficiency Gustav Vasa made monarchial rule hereditary. Until his reign, it was electoral. This gave a relative political stability especially in times of succession from one monarch to another. However the main point is not the hereditary rule. Lennart Andersson Palm, in Sweden's $17^{\text {th }}$ century - a period of expansion or stagnation?, emphasizes early modern Sweden's high degree of centralization and an increasingly effective state bureaucracy in comparison with many other European countries at that time (Palm, 2016: 1). Thanks to that, Sweden was in a much more advantageous position in using its resources effectively. The nobility, which Gustav Vasa crushed their rebellion, Westrogothian Rebellion (1529), was not strong enough to resist the state power. Also, A. F. Upton, in The Riksdag of 1680 and the Establishment of Royal Absolutism in Sweden, asserts that three lower estates of the Imperial Diet put a united and strong political force against the nobility (Upton, 1987: 285). So, the King usually allied with the peasantry (who feared from the expansion of the rights of the nobility) to get their support 
for a more centralized state. This efficiency is most obvious in the tax collection. Not only this but also Gustav Vasa's confiscation policy of the Church land and property increased the state incomes.

\subsubsection{Economics}

In terms of economics, Sweden was not only successful in tax collection. It was also successful in trade. Palm claims that, "during that century the country became one of the leading exporters of metal"' (Palm, 2016: 1). Palm proofs this statistically: Sweden in the beginning of the Industrial Revolution (in the beginning of the $18^{\text {th }}$ century) provided 82.5 per cent of England's iron imports and 40 per cent of its iron needs (Palm, 2016: 1). Not only this, but also Sweden had a monopoly on the European copper market for a long time (Palm, 2016: 1). So, one could deduce that, natural resources of the country were used effectively thanks to the centralized administration. This had a positive impact on the economy and this is one of the key reasons in explaining "why Sweden became a great power in the $17^{\text {th }}$ century".

\subsubsection{Military}

Another key reason is the success of the military. According to Francis J. Bowman, in Sweden's Wars, 1611 - 32, “Sweden ascended to the rank of a European great power, basing her position on her military accomplishments" (Bowman, 1942: 357). Sweden, in the beginning of the $17^{\text {th }}$ century, reorganized its military and made several military innovations.

For the reorganization and innovation of the military, Bowman gives the example of military reforms of Gustavus Adolphus. After the Kalmar War (1611 - 13) which was fought against Danes, the King recognized the untrustworthiness of the mercenaries and untrained militias (Bowman, 1942: 358). Sweden failed to reach its objectives in the Kalmar War, so something should be done in the military.

Gustavus Adolphus observing that, studied on the siege operations and the coordination of light cavalry with heavily armed infantry (Bowman, 1942: 358). Not only this, but he also "increased the percentage of musketeers as compared to the number of pikemen in his brigades, and emphasized mobility over masses" (Bowman, 1942: 359). Also, reliance on river lines and transportation on them was improved (Bowman, 1942: 359). A new formation was given to the artillery regiment: garrison, siege, heavy and light field battalions (Bowman, 1942: 360). In short, it would be correct to deduce that, Sweden was adopting itself to the "early modern" warfare. Especially the new formation of the artillery regiment was imitated by the other European armies (Bowman, 1942: 360). 
Swedish intervention $(1630-48)$ in the Thirty Years' War $(1618-48)$ proofs the success of the reorganization and innovations in the military. Mobile, light field artillery of Swedes supported the infantry directly on the battlefield. In addition to this, flexible and mobile formations of the infantry and excellent generalship brought victories to Swedes. However, this does not mean that, alliance with France was no less important in the Sweden's successes in the Thirty Years' War. French subsidies were also helpful but it was Swedish military who won the battles. Also, as emphasized in the introduction, it was Sweden, not France, who was credited with saving Protestantism in Germany.

\subsubsection{Financing the Military}

Financing the military and the battles were the crucial point for the successes. Sweden especially until the mid. $17^{\text {th }}$ century was successful in that aspect. Jan Glete, in The Swedish fiscal-military state in transition and decline, 1650 - 1815, studies on the economic aspect of the wars of Sweden from the second half of the $17^{\text {th }}$ century to the end of the Napoleonic Wars. However, his study also includes deductions for the first half of the $17^{\text {th }}$ century. According to him, precondition for Sweden's expansion was its ability to quickly send a major combat-ready army, supported by a large navy to the continent (Glete, 2006: 4). The army must be strong enough to defeat the enemy immediately and the navy must be able to protect the lines and the Baltic Sea (Glete; 2006: 4). "That meant that Sweden must maintain large, domestically financed armed forces"' (Glete, 2006: 4) with the administrative ability to mobilize and concentrate resources (Glete, 2006: 4). Glete claims that, before 1650, only few European powers maintained large permanent armies and navies (Glete, 2006: 4). The comparison of this large permanent armies and navies shows that, with the exception of Dutch Republic (Glete, 2006: 4), "none did it on the same per capita level as Sweden' (Glete, 2006: 4). This shows the success of the Swedish state in financing its military.

\subsection{Conclusion on the Rise of the Swedish Empire}

In conclusion, gaining its independence in the first half of the $16^{\text {th }}$ century and reaching a high degree of centralization and bureaucratization at the beginning of the $17^{\text {th }}$ century, Sweden became a great power in that century. Its rich natural resources and also the effective usage of these resources with the centralized administration proved to be successful. The finance of the military, military reforms and innovations were successful, too. With its military accomplishments, Sweden was able to rule a great empire in the northern Europe which its influences would exceed to the whole Europe, even to the New World. Today, 
discussions about the history of the northern Europe and even the Europe as a whole could not be understood without studying the history of the Swedish Empire.

\section{The Industrial Development in Sweden}

The industrial developments of $19^{\text {th }}$ century are one of the most influential periods of history which shaped today's world. In that period, Europe saw major developments and changed both itself and the world. In $19^{\text {th }}$ century, from starting a very low base, Sweden saw unprecedented economic growth rate between 1850 and 1970, thanks to her industrial development. Today, it is one of the wealthiest nations in the world. Even in economics, this is called "the Swedish model" and by many economists, the Swedish model get suggested to countries in the process of industrialization. In today's world effects are still visible. Between 1850 and 1910, approximately one million Swedes immigrated to the United States of America. But today, Sweden, by being one of the wealthiest nations in the world, is the "dream country" of many people. So, one could ask the question of "what was the form that the industrial development took in Sweden and what was its effects on the Swedish society'. Before answering this question, some background information on the history of Sweden would be helpful.

\subsection{Background of the Industrial Development in Sweden}

During the reign of Gustav Vasa (also known as Gustav I of Sweden) (1496 - 1560 / r. 1523 - 1560), he followed an autocratic rule; the Sweden saw an early modern centralization, the Reform movement in religion, important reforms in administrative, economic and military areas. Gustav Vasa's rule prepared Sweden to be a great power in $17^{\text {th }}$ century.

In $17^{\text {th }}$ century, Sweden dominated much of the northern Europe and even had overseas colonies or trading posts in North America, Caribbean and Africa. Although most of them failed, they are important examples to show the extent of the Swedish imperial power. Economic and political effectiveness, usage of natural resources wisely, innovation and successes in military all made Sweden a major European power.

With the Great Northern War $(1700-21)$, especially with the defeat of Swedish forces in the Battle of Poltava (1709), Sweden ceased to be a major European power. This disastrous defeat was followed by "Age of Liberty" which saw for a half century parliamentary rule and increasing civil rights in Sweden. Sweden was considered as an "enlightened absolute monarchy". Since we looked to the history of Sweden as background, now is the time to 
explain the $19^{\text {th }}$ century Sweden with the outline that industrial development took there and its effects on Swedish society.

\subsection{How did the Sweden industrialized?}

In terms of chronology, Sweden was a late-comer of Industrial Revolution. By historians, Industrial Revolution's starting point and place mostly considered as the mid. $18^{\text {th }}$ century Britain. The spread of Industrial Revolution took place in continental Europe only after the end of French Revolutionary Wars (1792 - 99) and Napoleonic Wars (1801 - 15). According to Fischer in "Sweden during the Industrial Revolution", Sweden "missed much of the first industrial revolution (to 1850)" (Fisher, 1992: 190). In terms of GDP per capita too, Lennart Schön and Olle Krantz in "The Swedish economy in the early modern period: constructing historical national accounts" argues that, although first half of the $19^{\text {th }}$ century was a recovery period for Sweden, it was only the late $19^{\text {th }}$ century when Sweden experienced "the real breakthrough of economic growth" (Schön and Krantz, 2012: 543). Schön and Krantz support their arguments with graphics in terms of annual GDP per capita and also with tables such as annual volumes in constant prices (Schön and Krantz, 2012: 544). So, all these evidence show that, Sweden's industrial development mostly happened in the second half of the $19^{\text {th }}$ century. However this fact only increases a researcher's interest in the industrial development of Sweden. Since the time span is shortened, the success story becomes more "successful”,

\subsubsection{Natural Resources and the Raw Material Industries}

First of all, Sweden was rich in natural resources such as iron, copper, silver, wood, tar and herring (made into oil). Especially iron and wood were important. According to Lennart Schön, the industrial growth in Western Europe in mid. $19^{\text {th }}$ century increased the demand for raw materials such as iron and wood (Schön, 2019). So, this situation increased prices sharply and Sweden, by being at the right place at the right time, increased its exports on "bar iron, wood and oats"' (Schön, 2019). Schön also adds Crimean War (1853 - 53) as an important factor for the increasing demand of these materials (Schön, 2019). Sweden benefited from this also in an indirect way. In the following decades, modernization of the Swedish steel industry happened and even today it is one of the strongest ones in the world. So, although lacking coal reserves (unlike Britain), Sweden's rich iron and wood resources contributed to its industrial development significantly. 
Lennart Erixon, in "The Golden Age of the Swedish Model", asses these industries as "raw material industries" which their demands fluctuate on a yearly basis and also they do not require advanced technologies (Erixon, 1997: 12). Erixon claims that, these raw material industries, in addition with the agricultural surplus (which is a result of the increased population and agricultural revolution of $18^{\text {th }}$ and $19^{\text {th }}$ centuries) created the base for the "real breakthrough" of Swedish industrialization which happened at the beginning of $1870 \mathrm{~s}$ (Erixon, 1997: 12). He defines this period as "the first innovation wave" (Erixon, 1997: 13).

\subsubsection{The First Innovation Wave and the Entrepreneurship}

In the first innovation wave, we see companies, which most of them were domestic in engineering and electricity centered business areas. Some examples are Atlas Copco (est. 1873) which was specialized on railway equipment (primarily carriages), Ericsson (est. 1876) which was a telephone company, Alfa-Laval (est. 1883) which was specialized on dairy machinery industry, ASEA (est. 1891) which was specialized on long distance transfers of electricity, AGA (est. 1904) which was specialized on gas for medical and industrial use and finally SKF (est. 1907) which was specialized on ball bearings (Erixon, 1997: 13). Most of these companies were leading producers in their specialized areas and were known worldwide. These are important examples which shows the wide spread entrepreneurship in late $19^{\text {th }}$ century Sweden. One could claim that, mid. $19^{\text {th }}$ century industrial developments with the raw material industries created the base for the first innovation wave which would make Sweden an industrial country.

\subsubsection{The Swedish Government and the Industrialization}

While studying this, one could not ignore the position of the government. Andreas Bergh in "The Rise, Fall and Revival of the Swedish Welfare State: What are the Policy Lessons from Sweden?" gives a list of Swedish governments' actions which contributed to the industrial development of the country (Bergh, 2019: 4). They could be divided into three categories such as education related, economy related and bureaucracy related. Education related ones are establishment of Royal Institute of Technology (1826) and compulsory elementary school (1842) (Bergh, 2019: 4). Economy related ones are abolishment of compulsory guild training (1846), introduction of joint stock company law (1848), lowered tariffs (1850s), establishment of freedom of trade (1864), removal of interest rate control (1860s), monetization of the taxation system (1869), introduction of gold standard based Swedish Krona (1873) and The Companies Act (1895) (Bergh, 2019: 4). These government 
actions related to economy shows a monetization in the economy and also, regulations to increase the productiveness and effectiveness of free trade. In terms of state bureaucracy, one sees the abolishment of aristocratic prerogative for higher positions in the state (1845), replacement of parishes with municipalities (1862), establishment of the modern Swedish parliament instead of four estates system (1866) and a number of reforms on the responsibilities and position of civil servants (1855 - 75) (Bergh, 2019: 4). Bergh defines these actions as the introduction of a Weberian type bureaucracy. One could see that, there is a general trend towards more rationalization of the state apparatus. With these, again, productiveness and effectiveness would be increased.

In short, in $19^{\text {th }}$ century Sweden, we see that government supported the industrial developments by supporting education (which would contribute to the first innovation wave), issuing laws on the economy (which would contribute to finance the industrial development of the country) and with significant reforms in the state apparatus (which would modernize the country and also create the "fertile ground" for other developments).

\subsection{The Effects of Industrialization on the Swedish Society}

This was the form that industrial development took in Sweden. Then the next question is the effects of this development on the society. Like any country which experienced industrial developments, it had major effects on the society. Urbanization is one of the most obvious effects on the society. Sören Edvinsson and Hans Nilsson in "Swedish Towns during Industrialization" study on the urbanization and transformation of urban settlements in industrializing Sweden in $19^{\text {th }}$ century. According to them, until to mid. $19^{\text {th }}$ century, only 10 percent of the population was living in urban areas (Edvinsson and Nilsson, 1999: 67). Not only this, but also these urban areas were small, in comparison to other European urban areas (Edvinsson and Nilsson, 1999: 67). Some visitors described Swedish cities as "towns looked like villages"'(Edvinsson and Nilsson, 1999: 67). But after mid. 19 th $^{\text {century, the internal }}$ migrations changed the nature of cities and the urbanization of the country began. So, although until 1930 most of the population still lived in rural areas, historians defines this internal migrations and urbanization as a "demographic transition" (Edvinsson and Nilsson, 1999: 67).

Industrial developments also changed the occupational structure of the country. Ineke Maas and Marco H. D. van Leeuwen in "'Industrialization and Intergenerational Mobility in Sweden" study on this transformation of occupational structure of Sweden. According to them, after the beginning of industrialization of country in mid. $19^{\text {th }}$ century, total mobility in 
the society was increased (Maas and Leeuwen, 2002: 190). They choose Sundsvall region as a case study and by studying it, they prove that "occupational distribution of male labor force" (Maas and Leeuwen, 2002: 184) changed significantly (Maas and Leeuwen, 2002: 184). Unskilled labor force increased in number. Also the number of skilled labors increased too, but it was smaller and happened later. The agricultural groups such as farmers, crofters and farmhands, declined (Maas and Leeuwen, 2002: 184). So, the industrial developments changed the occupational structure of the country significantly, making Sweden an industrial country rather than an agricultural country.

\subsubsection{The Labor Movements and the Swedish Social Democracy}

These changes and formation of an industrial work force caused repercussions in the form of popular movements such as the labor ones. During mid. $19^{\text {th }}$ century, at the beginning of industrial developments, there were some reforms on the issues of "national responsibility for old age, unemployment and sickness" (Valocchi, 1992: 194). However, Steve Valocchi in "The Origins of the Swedish Welfare State: A Class Analysis of the State and Welfare Politics" defines these early reforms only as "extensions of previous programs" (Valocchi, 1992: 194). Valocchi claims that, there were close links between local authorities, politicians and bureaucracy and this helped the civil servants to solve problems on a national but ad hoc basis (Valocchi, 1992: 194). However, with the progression of industrial developments, things changed significantly.

In 1879, Sweden saw its first major strike which was organized by labor groups (Valocchi, 1992: 195). In the next three decades too, strikes, formation of trade unions and related socialist activities flourished (Valocchi, 1992: 195). So, this transformation of the society was not as smooth as one could expect from Sweden, given the fact that today's Sweden is a world wide known good example. The following reforms by the governments created what today known as "Swedish welfare state'. But since many of these reforms happened after the end of World War I (1914 - 18), this emergence of the Swedish welfare state is out of the scope of this paper. In that paper, in the period in question, one sees that Sweden is not an exception in terms of labor uneasiness caused by the transformation from an agriculturally based economy to an industrially based economy. The success of Sweden comes in the handling of these problems by the governments. Unlike many other countries of continental Europe, Swedish governments, with the influence of social-democratic policies, created a welfare state and kept both far right and far left revolutionary threats at the bay. One could even assert that, the famous Swedish neutrality in World War I and World War II (1939 
- 45) was achieved thanks to such governmental policies which avoided polarization of the society in a world where everything was polarized.

\subsection{Conclusion on the Industrial Development in Sweden}

In conclusion, although Sweden was a late-comer to Industrial Revolution (which was already started in mid. $18^{\text {th }}$ century in Britain) in mid. $19^{\text {th }}$ century, with its rich natural resources, by developing raw material industries (such as iron and wood) which would provide the highly demanded raw materials in the world (main export partner of Sweden, was Britain at that time) created the base for further industrial developments. In late $19^{\text {th }}$ century, this base gave way to various entrepreneurships in engineering and electricity businesses and made Sweden an industrial country in Western Europe. The governmental policies and reforms in education, economics and finance proved to be successful in their contribution to industrial development of the country. Not only this, but also rationalization of the bureaucracy in Weberian sense also made the state apparatus ready, both for supporting industrial developments and also coping with problems which would arise from these developments.

Developments in industrial area had major effects on society which were urbanization of Sweden, significant changes in the occupational structure of the country (decline in the agricultural works but an increase in unskilled and skilled labor force) and labor uneasiness in the form of strikes, formation of trade unions and spread of socialist ideas. Following reforms by the governments in response to these problems also proved to be successful and created today's Swedish welfare state. The success of the Swedish model attracts the attention of politicians, economists, historians, academicians and also general public. The studies on it still continue with the hope of changing the world for better, with the inspiration and lessons to be taken from the Swedish case.

\section{Conclusion}

Sweden, by implementing a religious Reformation and building an autocratic rule in $16^{\text {th }}$ century, by becoming a major European power in $17^{\text {th }}$ century and by becoming an industrialized country in the second half of the $19^{\text {th }}$ century has a remarkable history which has strong implications for today. The rise and fall of great powers have always become an area of interest for historians, political scientists, statesmen and also general public. The rise of the Swedish Empire with its background in the $16^{\text {th }}$ century Reformation and the rule of Gustav I of Sweden complete an important part, chronologically the early modern part of this 
story. However there is also a second, chronologically modern part of the story: The industrial development in Sweden. Together these events, which include many different processes and factors studied above created a second success story (if we consider the early modern part as a "success") which resulted in the emergence of the modern Sweden.

Overall in these complex processes and different factors which influenced the three phenomena studied above, there are some common patterns. We see the abundance and also effective usage of natural resources, an able state bureaucracy and military and also governments' right policies on economy and society. Together all these, made Sweden what it is today. Not only this, but also the lessons from the Sweden's history might help to policy makers in other developing countries (and also for some areas, developed countries too) to change their country for better.

\section{REFERENCES}

Arrison, John G. (1994), "Time Capsule from the $17^{\text {th }}$ Century: Stockholm's Vasa Museum." Technology and Culture 35, 1, $158-167$.

Beck, Andrew (1940), “The Rise and Fall of Catholic Sweden.’ An Irish Quarterly Review $29,115,382-394$.

Bergh, Andreas (2011), “The Rise, Fall and Revival of the Swedish Welfare State: What are the Policy Lessons from Sweden?," IFN Working Paper, 873, 1-29.

Bowman, Franscis J. (1942), “'Sweden's Wars, 1611-32.’ The Journal of Modern History 14, $3,357-369$.

Edvinsson, Sören, Hans Nilsson (1999), “Swedish Towns during Industrialization.” Annales de demograhie historique, 2, 63-96.

Erixon, Lennart (1997), “The Swedish Growth Engine.' In The Golden Age of the Swedish Model - The Coherence between Capital Accumulation and Economic Policy in Sweden in the Early Postwar Period, Oslo: Institute for Social Research, 12-21.

Fisher, Douglas (1992), “'Sweden during the Industrial Revolution.' In The Industrial Revolution, 190-223. London: Palgrave Macmillan, 1992. 
Glete, Jan (2006), “The Swedish fiscal-military state in transition and decline, 1650-1815.” paper to the XIV International Economic History Congress, $1-16$.

Gonzalez, Joseph (2006), “'Rewriting History: Humanist Oration at the Funeral of Gustav Vasa, 1560.' Scandinavian Studies 78, 1, $21-42$.

Jonsson, Inge (1999), "Swedish Culture in a European Context." Proceedings of the American Philosophical Society 143, 1, 148 - 156.

Maas, Ineke, Marco H. D. van Leeuwen (2002). 'Industrialization and Intergenerational Mobility in Sweden.' Acta Sociologica 45, 3, 179-94.

McKeown, Simon (2009), “Reading and Writing the Swedish Renaissance.' Renaissance Studies 23, 2, $141-150$.

Palm, Lennart Andersson (2016), Sweden's $17^{\text {th }}$ century - a period of expansion or stagnation?. Göteborg: Institutionen för historiska studier, Göteborgs universitet, 2016.

Schön, Lennart, "Sweden - Economic Growth and Structural Change, 1800-2000." Accessed May 11, 2019. https://eh.net/encyclopedia/sweden-economic-growth-andstructural-change-1800-2000/

Schön, Lennart, Olle Krantz (2012). “"The Swedish economy in the early modern period: constructing historical national accounts.' European Review of Economic History 16, 4, 52949.

Skarsten, Trygve R. (1980), “The Reception of the Augsburg Confession in Scandinavia." The Sixteenth Century Journal 11, 3, 86 - 98.

Thuringer, Rune P. (1973), “The Catholic Church in Sweden.” The Furrow 24, 2, 67 - 74.

Encyclopedia Britannica. “Church of Sweden.' britannica.com. https://www.britannica.com/topic/Church-of-Sweden (accessed November 10, 2018). 
The Reformation. "The Reformation in Scandinavia." thereformation.info.

https://www.thereformation.info/scandinavia/ (accessed November 10, 2018).

The World Wide Web Virtual Library. "Chapter 12: The Reformation in Germany and Scandinavia." vlib.iue.it. http://vlib.iue.it/carrie/texts/carrie_books/gilbert/12.html (accessed November 10, 2018).

University of Wisconsin-Madison. "Sweden in the Seventeenth Century." faculty.history.wisc.edu/sommerville.

https://faculty.history.wisc.edu/sommerville/351/Sweden.html (accessed December 15, 2018).

Upton, A. F. (1987), “The Riksdag of 1680 and the Establishment of Royal Absolutism in Sweden.' The English Historical Review. 102, 403, (1987). 281 - 308.

Valocchi, Steve (1992). “The Origins of the Swedish Welfare State: A Class Analysis of the State and Welfare Politics" Social Problems 39, 2, 189-200. 